\title{
The Sakha and the Evenk: \\ Fundamentals of Common Conceptual Space
}

\author{
Evdokiya N. Afanasieva \\ and Raissa P. Ivanova* \\ Mirny Polytechnic Institute (branch) of \\ Ammosov North-Eastern Federal University \\ 5/1 Tikhonova Str., Mirny, Sakha Republic, 678170, Russia
}

Received 09.09.2016, received in revised form 16.09.2016, accepted 05.10.2016

The article deals with the problem of linguistic contacts and their impact on worldview of the Evenk and Sakha. Mythology, language and folklore of these peoples have common features. The concept of the universe has three levels in both cultures. The God is in heaven, people are in the middle world, devils are in the lower world. In the Sakha epic heaven is the place of not only gods but also some evil spirits and ancestors. The Evenk imagine heaven as paradise, no evil spirits live there. The warriors of the middle world travel to the upper world to search for the brides. Close contacts and neighbouring during long-time period and family ties between the Evenk and Sakha had led to the formation of the common conceptual space based on religious and cultural syncretism, intermixture of the mythological and epic worldview.

Keywords: Evenk, Sakha, Altaic languages, concept, linguistic contacts, epic, mythology, Yakutia.

DOI: 10.17516/1997-1370-2016-9-10-2298-2304.

Research area: philology.

\section{Introduction}

According to the Altaic theory, the Turkic, Mongolic and Tungusic peoples had common Altaic origin and spoke the same language during the Altaic epoch (Tenishev, 1996: 7-16).

Many linguists consider the common features of the Altaic languages to be the result of linguistic contacts. The interaction between the Turkic, Mongolic and Tungusic languages was durable and intensive and took 1,5-2 thousand years (Scherbak, 2012: 132).

German scholar K. Schönig wrote about the great role of the interaction between the languages during the Proto- and Pre-Proto-Turkic-Mongolic periods (Schönig 2005: 132).

As a result of these interactions the peoples had formed a common conceptual system of the world. In eastern philosophy the triad HEAVEN-MAN-EARTH makes up the basic concept. This is testified by Orkhon Mongolian written records dating back to $8^{\text {th }}$ century (Barthold, 1897: 5). The Chinese and TurkicMongolian peoples worshipped the God of the Heaven "Täyri”" (Barthold, 1897: 9; Gumilev, 2007). Already in the $11^{\text {th }}$ and $12^{\text {th }}$ centuries the Turkic named the God kök tägri (blue sky,

(C) Siberian Federal University. All rights reserved

* Corresponding author E-mail address: Raissa1@yandex.ru, Lukow@mail.ru 
heaven). The life depended on the heaven's will (Barthold, 1897: 10).

Heaven and Earth are opposed to each other and symbolize good and evil, purity (heaven) and sinfulness (earth) (Bavdinov, 2007: 28-29). In mythology Heaven symbolizes male being, while Earth stands for female. The Mongolic tribes addressed Heaven as "Father" and Earth as "Mother" (Shojsorova, 2006: 11).

The mythological picture of the world manifests itself in the language: the Chinese word tjan and ancient Turkic kök tägri have the meanings of Heaven and God at the same time. Investigators consider Heaven worshipping to be the fundament of traditional worldview of the Turkic-Mongolic tribes and cultural issue of nomadic tribes in Sayano-Altay and Central Asia (Abaev, N. V., Fel'dman, V. R., Hertek, L. K., 2002: 13). The triad HEAVEN-MAN-EARTH can be found in the mythology of the Sakha and the Evenk that have been living in neighbourhood in Eastern Siberia for more than eight centuries.

\section{The Universe in the Folk Epic Olonkho of the Sakha}

In the epic poetry of the Sakha, the Universe consists of three levels: Earth in the middle, Heaven at the upper level and Hell at the lower one. The Universe is presented as a giant tree Aal Luuk Mas, which contains these three levels of human existence. The lower level represents the underworld; the upper is the habitat of the deities and also some evil spirits. The lower level belongs to the devil - abaahy (old Turkic abači devil DTS). The middle level is inhabited by the ajyy people (Turkic aji-creation, work DTS). The life on the Earth depends on the will of the upper spirits, and the lower level habitants threaten the lives of the middle world habitants. The Earth and Heaven represent a unity. Heaven symbolizing spirituality and Earth being a material entity which depends on the Heaven.
Animism is the principal feature connected with the surrounding world. The three levels of the universe are inhabited by gods (ajyy), demons (abaahy), spirits (itchi), spirits of ancestors and animals (üör). The eastern and western parts of the upper world were inhabited by creators (ajyy), good spirits, ancestors, white shamans and other nobility. The western side and a part of the southern side of the heaven was a place of the evil spirit and abaahy ruled by the menacing Uluu Toyon (Vasiliev, 2006: 89-90). Heavenly bodies influence the life on the Earth. The Earth is named as a place of the Sun (kyun sire), the God is compared with the Sun (kyun tangara).

The upper god Yurung Aar Toyon (the White Master, the White Creator, the White Old Man) rules the destinies of the people of the Earth. In the epic Er Sogotoh (The Lonely Warrior) the hero addresses the heaven with a prayer: "The Great Heaven Master, Yurung Aar, the Majestic Possessor of the nine white layers of the heaven..." (Er Sogotoh, 1991).

In Olonkho, Heaven has 7 (sometimes 8, 9) layers and 4 parts (East, West, North and South). Yurung Aar Toyon is the Master of 9 heavens, the Tsar of 8 heavens, the prince of 7 heavens: "to5us hallaan tojono, a5ys hallaan yraahtaa5yta, sjettje hallaan kinjejehje" (Kuruubaj Haannaah Kulun Kullustuur, 1985: 1420).

The heaven writers put down the destiny of each person: "Hallaan giene alta atyyr / D'yl5a suruksuttara / Hallaan arkyabatyn aryjan kerbyttjer" (6 heaven destiny writers checked the heaven record) (Kuruubaj Haannaah Kulun Kullustuur, 1985: 2390). Shamans turn into clouds and travel through the heaven 'ojuun olorbut ojuk bylyta' a lonely cloud, where a shaman sat, 'Abaahy naj hara bylyta' a dark cloud of the evil spirit, 'iirer menegejdeeh bylyt ichchite, Ilbis kyyha' the goddes of war, spirit of insane cloud. Every cloud in the sky has its own characteristics: 'aahar bylyt' is a 
passing cloud, 'kuotar bylyt' is an escaping cloud, 'uulaah-haardaah naj hara bylyt' is a dark hard rainy cloud, 'jetineh bylyttar' are thunderstorm clouds (Afanasieva, 2012: 136).

\section{The Universe in the Folk Epic of the Evenk}

In the Evenk epic the universe Buga consists of three levels: upper - Ugu Buga, middle Dulin Buga, lower - Hergu Buga. Ugu Buga, heaven, has several parts, Juri Jultjen Turinyn is the place of the rising sun, Jenin Nadar Bomchar is the mother of seven canyons and Nadan Buldjar is the land of seven seas (Varlamova, 2004: 20-22).

The Earth - Sivir is mentioned in the epic and poetry of the Evenk: "Sivir is the mane of our Earth, the middle, green world" (Varlamov, 2013).

The upper world is depicted as the place of the eternal summer, warmness and well-being. The God Seveki lives there, he is the creator of the middle world. The warriors of the middle world travel to the upper world to search for the brides - daughters of the sun Dylacha Khunadin, moon and stars Bega Khunadin. Buga also stands for the upper entity, which rules the powers of the nature, taiga life, animal and human lives. The mistress of the universe Buga Musin is depicted as a moose cow, a rein-deer, an old stooping woman who is in charge of human and animal spirits.

A human is the creature of the heaven Dylacha - sun , Gevan - dawn, Nyangnya heaven, sky.

The tribes are called ai, aji, agbea, aji ajmak, ai tegel. In the Tungusic-Manchurian languages the word aj denotes help, rescue, the word ajagood, beautiful (Cincius, 1975).

Their destination is creation of good in the middle and upper worlds of the Evenk. They are opposed to the Avakhi tribe from the lower world. They are constantly fighting, they never marry each other.

\section{Serge as the Model of the Universe}

Serge is a pillar for horse tethering. In the Sakha culture it represents a part of the shaman tradition and performs a ritual function. It is erected during celebrations, weddings, and summer holyday Yhyakh.

In the Evenk culture this ritual object symbolizes the world structure: it has three parts: the upper dome-shaped ledge stands for the upper world, the disc-shaped ledge for the middle world and the rounded ledge for the lower world (Bereltueva, 2013: 216). A sacred reindeer tethered to the pillar was a medium between the human and God - the Master of the upper world Seveki.

\section{The Impact of the Evenk Language on the Sakha Language}

A Finnish scholar Juha Janhunen highlighted the role of the linguistic interaction in the formation of the Ural-Altaic linguistic community. He studied the historical contacts of the Tungusic languages and singled out protolinguistic, post-proto-linguistic and colonial periods. In the proto-linguistic period ProtoTungusic interacted with the Proto-Mongolic, Proto-Amuric, Proto-Japanese and Proto-Korean languages. Other neighbours were in the west Turkic, in the north-east - Uralic and ChineseTibetan in the south-west.

As far as lexical ties are concerned, Janhunen explains that the lexical parallels are typically the item of cultural vocabulary, passed from Turkic to Mongolic and then to Tungusic (Janhunen, 2013: 32).

In the post-proto-linguistic period the process of interaction of peoples and their languages continued during a millennium on a vast territory; in Western Siberia on the banks 
of the rivers $\mathrm{Ob}$, Yenisei, in the lower reach of the Amur and the Sea of Okhotsk, around Lake Baikal, along the Arctic coast, on Sakhalin and Kamchatka. According to Janhunen the Tungusic languages fall into four principal branches: Jutchen-Manchu (Jurchenic), Udeghe-Oroch (Orochic), Nanaj-Ulcha-Orok (Nanaic), and Ewenki-Ewen (Ewenic) (Janhunen, 2013: 34).

In the third colonial period in the Northeast Asia the three state languages were dominant: Russian, Chinese and Japanese. Great historical events in Russia, China and the Far East from the $16^{\text {th }}$ until $20^{\text {th }}$ centuries drove the Tungusic tribes to the North.

The Tungusic languages had divided into two main territorial groups: languages in the Russian part and languages in the Chinese part (Manchu). Further on they had spread to Japan and the Middle Asia (Janhunen, 2013).

The nomad camp of the Tungusic tribes occupied a vast territory from the Far East to the Urals, from Siberia to Mongolia and China. The Tungusic-Manchurian languages are divided into two groups: Northern and Southern. The Northern group includes the Even, Evenki, Negidal and Solon languages. Peoples who speak these languages inhabit the north of Russia, Siberia, the coast of the Sea of Okhotsk and in a lesser amount in China. The Southern group includes Nanaj, Goldic, Orok, Oroch, Udeghe and Olcha. Their speakers live in the Amur basin and its feeders, also on Sakhalin Island. That is why, as we regard it, the Tungusic tribes could have been a linker of all the Altaic languages.

The Evenk have been a long-time neighbour of the Sakha on the territory of Eastern Siberia. The specific study of the interaction between the Evenk and Sakha languages was given in the work of A.V. Romanova, A.N. Myreeva and P.P. Barashkov. The impact of the Evenk on the Sakha language considers phonetics, morphology, vocabulary of the local speech and dialects in the north and south of Yakutia. Investigations on linguistic contacts helped to define the size and borders of interaction of the Sakha and Evenk languages (Novgorodov, 2009).

In phonetics:

- the sounds $g, h, p$ never occur in the beginning of a word;

- the pharyngal $h$ is not registered in Old Turkic written records, but appeared later;

- the impact of the Evenk intonation on some dialects of the Sakha, partial loss of vowel and diphthong length, the substitution of the front lingual $Y$ by back lingual $y$, uvula $h$ by back lingual $k$, uvula $\gamma$ by back lingual $g$, the loss of assimilation of consonant sounds.

In morphology:

- the borrowing of the affix -chaan from Evenki;

- the borrowing of the affix -ndja, -ndaa for designation of bigness (Romanova, 1975).

In vocabulary:

- the borrowing of the words denoting landscape, flora and fauna, clothing, reindeer breeding, dwelling.

A Polish scholar S. Kaluzhinsky relying on the lexicographical data of the Evenk and Sakha languages (Pekarskij, 1958; Afanasiev, 1976; Romanova, 1975) counted 400 words of Tungusic origin in the Sakha language. He also brings a list of words which were not registered in the studied data: akaary for studid, baatyly/ bootulu for hedge on pickets, burgunas for a three-year-old cow, icheen for a visionist, kehii for a present, mutukcha for a pine needle, nokhto for heart cords, sepereek for a bush, sibien for a spirit, tyna for lungs, turaan for silence, uuchakh for reindeer, yssen meaning to have a snack, ylygynej meaning to talk in sleep (Kałużinsky, 1982). Probably the Evenk words were borrowed by the Sakha in the period of their adaptation to new living conditions. The greatest amount of words borrowed denotes fir clothes and names of 
birds. The geographical names, words denoting animals and plants describe marshy lowlands with specific flora and fauna. The terminology connected with reindeer breeding enriched the vocabulary of the Sakha language.

\section{Conclusion}

Close contacts and neighbourhood during a long-time period and mixed marriages between the Evenk and Sakha led to the formation of the common conceptual space based on religious and cultural syncretism, intermixture of the mythological and epic world view.

The results of the convergent processes resulted in the formation of a common worldview and the similar perception of the world structure with subtle differences.

The semantic similarity includes both linguistic and cognitive spheres. Heaven in the epic worldview of the Sakha and Evenk has an identical multi-level structure. Though in the Sakha culture one does not observe a clear opposition of heaven and earth as good and evil. The opposition of Heaven-Earth in the Sakha culture is asymmetric unlike in other TurkicMongol cultures. Heaven is inhabited not only by gods but also by evil spirits and ancestors. For the Evenk heaven is like a paradise.

The sky God, the Creator of the Middle World ajyy is called "Yurung Aar Toyon" in the Sakha language and "Seveki" in the Evenk language. The Sakha call the middle world "ajyy land", and people "ajyy ajmaga". The Evenk call the inhabitants of all the three levels "aji". According to the Evenk epic the devils-enemies inhabit the lower world only. In the Sakha epic the evil spirits can be found in all three worlds.

One can see that ancient nomads - ancestors of the Sakha and Evenk interacted greatly which resulted in common conceptual space.

\section{References}

Abaev, N.V., Fel'dman, V.R. \& Hertek, L.K. (2002). 'Tengrianstvo" i “Ak-Chaiaan” kak dukhovno-kul'turnaia osnova kochevnicheskoi tsivilizatsii tiurko-mongol'skikh narodov SaianoAltaia i Tsentral'noi Azii ["Tengriism" and "Ak-Chaiaan" as a spiritual and cultural foundation of the nomadic civilization of the Turko-Mongol peoples of the Sayano-Altai and Central Asia], in Sotsial'nye protsessy v sovremennoi Zapadnoi Sibiri: Sbornik nauchnykh statei [Social processes in modern Western Siberia]. Gorno-Altaisk, 10-18.

Afanasiev, P.S., Voronkin, M.S. \& Alekseev, M.P. (1976). Dialektologicheskii slovar' iakutskogo iazyka [Dialectological dictionary of the Yakut language]. Moscow, Nauka, 390 p.

Afanasieva, E.N. (2012). Russkie leksicheskie zaimstvovaniia v iakutskom epose-olonkho "Kuruubai haannaah Kulun KullustuurI [Russian lexical borrowings in the Yakut epic-olonkho "Kuruubay haannaah Kulun Kullustuur"], in Vestnik Leningradskogo gosudarstvennogo universiteta imeni A. S. Pushkina [Bulletin of the Pushkin Leningrad State University], Saint-Petersburg, 2 (7), 183-193.

Barthold, W. (1897) The historical significance of the Old Turkish inscriptions in Radloff W. The Old Turkic inscriptions of Mongolia [Die historische Bedeutung der alttürkischen Inschriften, in Radloff W. Die Alttürkischen Inschriften der Mongolei]. St. Petersburg, 1- 36.

Bavdinov, R.R. (2007). Istoriko-kul'turnoe prostranstvo kontsepta 'zemlia' v drevneuigurskom iazyke: semanticheskii potentsial i religioznaia konnotatsiia (predvaritel'nye materialy) [Historical and cultural space of the concept 'land' in the Old Uyghur language: semantic potential and religious connotation (preliminary materials)], in Vestnik VEGU 
[Bulletin of Eastern University of Economics, the Humanities, Management and Law], 29/30, 24-29.

Bereltueva, D.M. (2013). Iazykovye relikty v obriadovoi kul'ture evenkov [Language relics in ceremonial culture of the Evenk]. Proceedings of the 11th Seoul International Altaistic Conference, December 5-7, 2013. The Altaic Society of Korea Institute of Altaic Studies, SNU, 215-221.

DTS - Drevnetiurkskii slovar' [Old Turkic Dictionary] (1969). Compiled by Nadeliaev, V.M., Nasilov, D.M., Tenishev, E.R., Shcherbak, A.M. (1969). Leningrad, Nauka, 715 p.

Gumilev, L.N. (2007). Drevnie turki [Ancient Turks]. Moscow, AST MOSKVA, 575 p.

Janhunen, J. (2013). The Tungusic Languages: A History of Contacts, in Current Trends in Altaic Linguistics, In The Altaic Society of Korea, 17-60.

Kaluzinsky, S. (1982). Some Turkish loanwords in Yakut [Einige türkische Lehnwörter im Jakutischen], In Acta Orientalia Academiae Scientiarum Hung. Tomus XXXVI (1-3), 261-269.

Novgorodov, I.N. (2009). Iakutsko-evenkiiskie iazykovye vzaimosviazi [Yakut-Evenk linguistic interconnections]. Author's abstract to the thesis. Kazan, 43 p.

Pekarskii, E.K. (1958-1959). Slovar' iakutskogo iazyka: v 3-kh t. [Dictionary of the Yakut language: in 3 parts]. Moscow, $3858 \mathrm{p}$.

Romanova, A.V., Myreeva A.N., Barashkov P.P. (1975). Vzaimovliianie evenkiiskogo i iakutskogo iazykov [Interference of the Evenk and Yakut languages]. Leningrad, Nauka, $211 \mathrm{p}$.

Schönig, C. (2005) Turkish-Mongolian language relationships [Türkisch-mongolische Sprachbeziehungen - Versuch einer Zwischenbilanz], In On behalf of the Society Uralo-Altaica [Im Auftrage der Societas Uralo-Altaica]. 19. Harrassowitz Verlag, 131 - 166.

Scherbak, A.M. (2012). O metodike issledovaniia iazykovykh parallelei (v sviazi s altaiskoi gipotezoi) [On the method of study of linguistic parallels (in connection with the hypothesis of the Altai)] Available at: http://www.altaica.ru (accessed 23 October 2012).

Shoisorova, E.S. (2006). Iazykovaia lichnost': etnicheskii aspekt : na materiale buriatskoi iazykovoi lichnosti [Linguistic identity: ethnic aspect: on a material of the Buryat language person]. Author's abstract to the thesis. Ulan-Ude, 2006, 190 p.

Tenishev, E.R. (1996). Altaiskie iazyki [Altaic languages], in Tiurkskie iazyki [Turkic languages]. Moscow, $543 \mathrm{p}$.

Tsintsius, V.I. (1975-1977). Sravnitel'nyi slovar' tunguso-man'chzhurskikh iazykov [Comparative Dictionary of the Manchu-Tungusic languages]. Leningrad, Nauka.

Kuruubai Haannaah Kulun Kullustuur. Iakutskoe olonkho [Kuruubai Haannaah Kulun Kullustuur. Yakut olonkho] (1985). Sang by Timofeev-Teplouhov, I.G., Moscow, Nauka.

Varlamov, A.N. (2013). Sivir, in Buga ganalchil : stihi [Buga ganalchil: poetry], Jakutsk: Ofset, $64 \mathrm{p}$.

Varlamova, G.I. (2004). Mirovozzrenie evenkov: otrazhenie v fol'klore [Worldview of the Evenk: reflection in folklore]. Novosibirsk, Nauka, $185 \mathrm{p}$.

Vasiliev, V.E. (2006). G.F. Miller i iakutskii shamanism [G. F. Miller and Yakut shamanism], in Rossiia - Germaniia: istoriko-kul'turnye kontakty. Mat. Mezhd.nauch. konf., posv. 300 - letiju so dnja rozhdenija G.F. Millera [Russia - Germany: the historical and cultural contacts. International conference on 300 - anniversary of the birth of G.F. Miller]. Yakutsk, 86-98. 


\title{
Саха и эвенки:
}

\section{основы единого концептуального \\ пространства}

\author{
Е.Н. Афанасьева, Р.П. Иванова \\ Политехнический институт (филиал) \\ ФГАОУ ВПО «Северо-Восточный федеральный университет \\ им. М.К. Аммосова» в г. Мирном \\ Россия, 678170, Республика Саха (Якутия), \\ г. Мирныци, ул. Тихонова, 5/1
}

\begin{abstract}
Многие исследователи объясняют общность алтайских языков как результат языковых контактов. В статье рассматриваются связи между эвенкийской и якутской лингвокультурами. В результате многовековых контактов и соседства у этих народов сформировалась единая концептуальная система мировосприятия. В мифологической картине мира основу мироздания составляет триада небо-человек-земля. В эпической поэзии Саха Вселенная представлена в виде исполинского дерева Аал Луук Мас, на котором расположены три среды существования человека, верхний, средний и нижний миры. Небо является средой обитания не только небожителей, но и некоторых злых духов. В среднем мире обитают люди айыbы. Нижний мир населяют племена абааһы (злые духи). Жизнь на Земле зависит от расположения небесных духов, а от обитателей нижнего мира исходит угроза для жизни людей. Земля и небо составляют единое целое, небо как духовное начало, а земля как материальная сущность, зависящая от неба. В эвенкийском эпосе вселенная Буга состоит из трех уровней: верхний мир Угу Буга, средний мир Дулин Буга (или Сивир), нижний мир Хэргу Буга. Верхний мир описывается как страна вечного лета, тепла и благополучия. В нем обитает божество Сэвэки - твореи среднего мира. Богатыри среднего мира в поисках невест поднимаются на верхний мир, где обитают дочери Солниа (Дылача Хунадин), Луны и созвездий (Бега Хунадин). Буга означает также верховное существо, управляющее силами природы, жизнью тайги, животных и человеческого рода.
\end{abstract}

Ключевые слова: алтайские языки, якутский язык, эвенкийский язык, эпос, концепт, когнитивная система, языковые контакты.

Научная специальность: 10.00.00 - филологические науки. 